\title{
Sal-Like Protein 2
}

National Cancer Institute

\section{Source}

National Cancer Institute. Sal-Like Protein 2. NCI Thesaurus. Code C117035.

Sal-like protein 2 (1007 aa, 105 kDa) is encoded by the human SALL2 gene. This protein is involved in the regulation of gene expression. 